\title{
Organizational Design Choices of High-tech Startups How Middle Management Drives Innovation Performance
}

Grimpe, Christoph; Murmann, Martin; Sofka, Wolfgang

Document Version

Accepted author manuscript

Published in:

Strategic Entrepreneurship Journal

DOI:

10.1002/sej.1330

Publication date:

2019

License

Unspecified

Citation for published version (APA):

Grimpe, C., Murmann, M., \& Sofka, W. (2019). Organizational Design Choices of High-tech Startups: How Middle Management Drives Innovation Performance. Strategic Entrepreneurship Journal, 13(3), 359-378. https://doi.org/10.1002/sej. 1330

Link to publication in CBS Research Portal

\section{General rights}

Copyright and moral rights for the publications made accessible in the public portal are retained by the authors and/or other copyright owners and it is a condition of accessing publications that users recognise and abide by the legal requirements associated with these rights.

Take down policy

If you believe that this document breaches copyright please contact us (research.lib@cbs.dk) providing details, and we will remove access to the work immediately and investigate your claim. 


\title{
Organizational Design Choices of High-tech Startups: How Middle Management Drives Innovation Performance
}

\section{Christoph Grimpe, Martin Murmann, Wolfgang Sofka}

\author{
Journal article (Accepted manuscript*)
}

\section{Please cite this article as:}

Grimpe, C., Murmann, M.., \& Sofka, W. (2019). Organizational Design Choices of High-tech Startups: How Middle Management Drives Innovation Performance. Strategic Entrepreneurship Journal, 13(3), 359-378. https://doi.org/10.1002/sej.1330

This is the peer reviewed version of the article, which has been published in final form at DOI:

$$
\text { https://doi.org/10.1002/sej.1330 }
$$

This article may be used for non-commercial purposes in accordance with Wiley Terms and Conditions for Self-Archiving

* This version of the article has been accepted for publication and undergone full peer review but has not been through the copyediting, typesetting, pagination and proofreading process, which may lead to differences between this version and the publisher's final version AKA Version of Record. 
ORGANIZATIONAL DESIGN CHOICES OF HIGH-TECH STARTUPS -

HOW MIDDLE MANAGEMENT DRIVES INNOVATION PERFORMANCE

Running head: Middle management and startup innovation

Christoph Grimpe

Copenhagen Business School

Department of Strategy and Innovation

Kilevej 14A, 2000 Frederiksberg, Denmark

ORCID iD: https://orcid.org/0000-0002-7644-205

Email: cg.si@cbs.dk

Leibniz Centre for European Economic Research (ZEW)

Department Economics of Innovation and Industrial Dynamics

L7 1, 68161 Mannheim, Germany

Martin Murmann

University of Zurich

Department of Business Administration

Affolternstrasse 56, 8050 Zürich, Switzerland

ORCID iD: https://orcid.org/0000-0002-0430-949X

Email:martin.murmann@business.uzh.ch

Institute for Employment Research (IAB)

Department Regional Labour Markets

Regensburger Strasse 104, 90478 Nuremberg, Germany

Leibniz Centre for European Economic Research (ZEW)

Department Economics of Innovation and Industrial Dynamics

L7 1, 68161 Mannheim, Germany

Wolfgang Sofka (corresponding author) Copenhagen Business School

Department of Strategy and Innovation

Kilevej 14A, 2000 Frederiksberg, Denmark

ORCID iD: https://orcid.org/0000-0003-1598-6127

Email:ws.si@cbs.dk

University of Liverpool Management School

Strategy, International Business and Entrepreneurship Group (SIBE)

Chatham Street, L69 7ZH, United Kingdom

Keywords: Middle management, entrepreneurial attention, innovation performance, startups, organizational design 


\title{
ORGANIZATIONAL DESIGN CHOICES OF HIGH-TECH STARTUPS - HOW MIDDLE MANAGEMENT DRIVES INNOVATION PERFORMANCE
}

\begin{abstract}
Research summary
Innovative products and services are the inspiration for many startups. However, founders find that the management of existing operations competes with the attention that they can devote to innovation. We investigate whether and how establishing a middle management level frees up attention for innovation when firms are newly started. We argue that middle management is positively related to introducing product innovations and that the effect is stronger when founders have larger stocks of pre-existing knowledge and when the startup's industry provides more innovation opportunities. These hypotheses are supported by an analysis of 2,431 German hightech startups founded between 2005 and 2012.
\end{abstract}

\section{Managerial summary}

Most high-tech entrepreneurs acknowledge that an overload of managerial tasks keeps them from advancing innovation in their startups. However, they are often times reluctant to introduce middle management because of a fear that the resulting bureaucratization will stifle innovation. Our study shows that these fears are not justified. Instead, we find for 2,431 high-tech startups in Germany that startups with middle managers are significantly more innovative than those without. While middle managers might be a roadblock for innovation in large firms, startups benefit from having them. Founders are the central decision makers in startups and can easily be overburdened with management tasks. Middle managers can alleviate parts of this workload and allow founders to focus on creating innovative products and services. 


\section{INTRODUCTION}

"We noticed that we had to do something to reclaim capacities for developing the firm and the product. I'm the driver of the firm and I push new product ideas. That's what I find fun. My motivation and my strength are product development."

Interview quote by the founder of an IT startup on how the creation of middle management helped innovation in his startup

Launching innovative products onto the market is a central element in the strategies of most startups in high-technology sectors (Wiklund \& Shepherd, 2003; Block et al., 2016). Having discovered an entrepreneurial opportunity, many startups find themselves in a race to realize that opportunity by introducing new products ahead of competitors or before their funding runs out (Venkataraman, 1997; Shane, 2000). During this critical startup phase in a firm's organizational lifecycle, entrepreneurs are typically the primary decision makers which challenges them to dedicate sufficient attention to innovation to be successful (Gifford, 1992; Zahra et al., 2009). By their very definition, innovation activities are novel and uncertain; they involve decisions about which technological path to choose and predictions about market conditions (Amit et al., 1990). Attention allocation is challenging since attention is a scarce resource and founders face tradeoffs when allocating attention to other tasks (Simon, 1948; Ocasio, 1997). In that regard, founders face opportunity costs on whether to allocate attention to the improvement of current operations or to innovation (Gifford, 1992). Hence, founders are likely to consider organizational design choices, which alleviate some of their attention constraints during the startup phase. However, extant literature has focused much more on later stages in the organizational lifecycle in which startups have already generated substantial sales (Daily \& Dalton, 1992), enter stable 
environments (Gedajlovic et al., 2004) or target initial public offerings (IPOs) (Wu \& Hsu, 2018).

In this study, we investigate whether startups can improve the likelihood of successful innovation by altering their organizational design to alleviate attention allocation tradeoffs. More specifically, we investigate the role of middle management, i.e., the delegation of decision making authority, for startup innovation. A startup's middle management may allow for better management of competing demands for attention and for better information processing related to innovation (e.g., Simon, 1948; Gifford, 1992). Although prior literature highlights how demanding and error prone innovation decisions are for the management of established firms (Koput, 1997; Katila, 2002), the effect of middle management on innovation in startups has not been documented in the theoretical and empirical literature. In short, this study focusses on the research question: Do startups with middle management have a higher likelihood for successful innovation than startups without?

Our theoretical reasoning revolves around the issue of how middle management can help entrepreneurs, oftentimes the founder or founding team of a startup, to dedicate attention to innovation vis-à-vis other tasks. We draw theoretical mechanisms from the literature on how middle managers increase a startup's information processing capacity, as well as free up the attention of founders (Colombo \& Grilli, 2013), and then integrate the mechanisms into a model of firm innovation that comprises search, selection, and implementation of new information, knowledge, and ideas (Koput, 1997). We reason that middle management allows founders to devote comparatively more attention to innovation, making startups more likely to introduce product innovations. Middle management can immediately take over responsibilities for managing current operations, allowing founders to devote more entrepreneurial attention to innovation. Moreover, mid- 
dle management provides information about current operations, permitting founders to better prioritize how to allocate attention. We rely on a contingency analysis that tests two situations in which the startup is particularly likely to benefit from founder attention to innovation, i.e., we investigate the size of the founder's existing knowledge base and the innovation opportunities available in the startup's industry.

We test our theoretical reasoning using a unique sample of more than 5,600 firm-year observations of 2,431 high-tech startups founded in Germany between 2005 and 2012. The information on these firms stems from linked employer-employee data that merges firm data from a panel survey with official registry data on the employees who work in these firms. Our reasoning is informed by a series of semi-structured interviews with startup founders and middle managers in startups that help us better understand the role and responsibilities of middle managers in such contexts. ${ }^{1}$ Our empirical study confirms that startups with middle management increase their likelihood to introduce product innovation and that this effect is stronger when founders have larger stocks of pre-existing knowledge and the startup industry provides comparatively more opportunities for innovation.

We advance existing literature in two important ways. First, we know comparatively little about how these early-stage changes in organizational design affect startups' innovation performance, arguably a core strategic goal of most high-tech startups. Our theoretical model introduces information processing and monitoring mechanisms from existing middle management literature into a model of founder attention allocation for innovation, providing a basis for future theorizing. This allows us to describe changes in the relationship between founders and "rank and

\footnotetext{
${ }^{1}$ Specifically, we conduct five interviews with startup founders and middle managers from different startups. The interviews lasted about one hour each and were conducted in an open way, including only few defined questions on the role of founders and middle managers, and how middle management frees up attention.
} 
file" employees when middle management affects the way in which information from these employees, such as requests or feedback on new materials or equipment from supplies or customers, becomes available to founders. What is more, we challenge existing literature, which investigates innovation outcomes of high-tech startups where founders have been replaced by professional management, by focusing on organizational design changes such as the introduction of middle management that occur before startups reach a threshold stage that requires further professionalization. These early stages of high-tech startups are particularly salient for research and practice since many startups run out of funding before they can create an innovative product.

Second, an emerging stream of entrepreneurship literature emphasizes how both founder experience and external opportunity shape startup success (e.g., Dencker \& Gruber, 2015). For innovation outcomes, we show that these theoretical models are incomplete in the sense that they underestimate the effect of the organizational design of startups. Our model takes into account how founders face tradeoffs for devoting sufficient attention to innovation. The contingency approach in our theory development suggests that middle management has particularly strong effects on startup innovation when founders are well prepared to innovate, i.e., have pre-existing knowledge stocks and industry environments in which the search for innovation pays off since many opportunities exist. These insights provide further room for theorizing about the direction of the reallocation of founder attention following the introduction of middle management, since the existing model comparing allocation to innovation or current operations appears to be too coarse (Gifford, 1992).

\section{THEORY AND HYPOTHESES}

Our theoretical reasoning lays out how the presence of middle management affects a startup's likelihood for introducing innovations in general, as well as how this general relationship is af- 
fected by two moderating factors. We start by outlining a model of firm innovation and highlight the role of attention allocation in the startup phase in which the founders are the key decision makers. We use this model to develop hypotheses on how middle management can help founders to allocate attention to innovation processes. In accordance with previous studies, we refer to the founders as the startup's highest management level that makes strategic decisions (e.g., Dencker \& Gruber, 2015), given that very few startups hire professional top managers early in their life cycle. Our terminology assumes that the hierarchical level below the founders (i.e., top management) is the middle management.

The role of entrepreneurial attention for the innovation process The focus of our theorizing is on the startup phase of new ventures. The startup phase is the initial stage of a firm's organizational lifecycle (Daily \& Dalton, 1992). During this stage, startups rely typically on their founders for strategic decision-making (Nelson, 2003), creativity and innovativeness (Zahra et al., 2009). Founders are uniquely positioned as chief decision makers for the dynamically changing environment of the startup phase since they combine the authority and legitimacy for centralized decision making as a startup's dominant shareholder (Gedajlovic et al., 2004). Literature suggests that these founder-manager advantages extend far into a startup's lifecycle until firms reach significant size thresholds (Daily and Dalton (1992), Walters et al., 2010).

Entrepreneurship in high-technology sectors is distinct from other industries in the sense that the generation of innovations is typically the defining purpose of such startups (Wiklund \& Shepherd, 2003). Entrepreneurs must discover and identify innovation opportunities where new technologies could be used (e.g., Venkataraman, 1997; Shane, 2000; Dencker \& Gruber, 2015). While innovation outcomes depend on many factors such as the availability of financial re- 
sources and skilled employees (Ahuja et al., 2008), management attention to innovation has been identified as particularly salient since most organizations tend towards stability and routine at the expense of innovation activities (Van de Ven, 1986).

Koput (1997) describes a formal model for an innovation process as a system in which two significantly different components interact. The first component involves the search for information, knowledge, and ideas that benefits from experimentation and unpredictability. The second component of the innovation process involves implementation, where innovation outcomes are efficiently and reliably produced. A screening function connects search with implementation, i.e., new ideas that may lead to innovations have to be evaluated and decisions about which ones to implement (and how) have to be made (Koput, 1997). Firms will be more innovative if they can allocate sufficient attention to decision making on search, screening, and implementation.

Attention allocation is a challenge for firms since (a) management attention is a limited resource for firms and managers face tradeoffs when allocating attention to other tasks (Ocasio, 1997; Kaplan, 2011) and since (b) search, screening, and implementation are not sequential processes but rather a dynamic, interconnected system with feedback loops. In sum, the model suggests that attention is key to regulate the flow of ideas and their implementation through innovation. Dahlander et al. (2016) highlight the importance of individual-level decision making on attention allocation and its effect on innovation outcomes. In this sense, attention can be defined as the cognitive processes by which individuals notice, interpret, and focus efforts, as well as the time spent on collecting information and knowledge (Kaplan, 2011; Li et al., 2013). The attention allocation of top management in particular determines innovation success.

While established firms can distribute attention for innovation among professional managers, decision making in the startup phase is typically dominated by the founders, whose decisions 
have vital influence on the firm (Wasserman, 2012). Founders have been found to be the central actors in the innovation process of startups, especially as a source of creativity (Marvel \& Lumpkin, 2007; Ahlin et al., 2014). Given that founders are typically responsible for all highlevel decision making in startups, opportunity costs for entrepreneurial attention are likely to emerge (Gifford, 1992; Acs \& Gifford, 1996). The innovation outcomes of startups will be negatively affected if founders cannot accurately and sufficiently identify new ideas or cannot devote the attention intensity necessary to evaluate them thoroughly (Li et al., 2013). Middle management and its effect on entrepreneurial attention for innovation The term middle management originates from the perspective that firms consist of at least two levels, i.e., top level decision makers, such as founders, and line workers (Rajan \& Wulf, 2003), even though startups oftentimes only consist of the founders for a prolonged period. The introduction of a hierarchical level in between, i.e., middle management, constitutes a major change in organizational design (Colombo \& Grilli, 2013). Middle managers are managerial or administrative specialists with delegated decision rights (Baron et al., 1999). They can reduce the ambiguity about the organization of work in a firm, improving coordination and efficiency (Sine et al., 2006).

Since all individuals are naturally limited in their capacity to acquire, store, process, and transmit information (Simon, 1948), the establishment of a middle-management level can improve the information processing capacity of startups (Colombo \& Grilli, 2013). The middle management of an organization allows it to handle a given amount of information more efficiently by enabling parallel information processing in which middle managers share information processing tasks with top management (Radner, 1993). Moreover, the establishment of a middle management level allows firms to use existing information processing capacities more efficiently 
by enabling hierarchical decision making (Garicano, 2000). Middle managers turn to top management only if their knowledge is insufficient to deal with a particular problem. In that sense, middle management can allow an organization to predict more accurately when problems or projects have reached a scope that benefit from organization-wide solutions that are most effectively addressed by top managers (Harris \& Raviv, 2002).

We conjecture that the improvement in a startup's information processing capacity derived from introducing middle managers alleviates the limitations on entrepreneurial attention that founders can allocate to current operations or innovation. Middle managers can, at least partly, take over the management of existing products and operations (Gifford, 1992). This allows founders to devote comparatively more attention to searching, screening, and implementing new knowledge and ideas to exploit innovation opportunities (Koput, 1997). Consistently, a member of the founding team of a software startup tells us:

"We decided to have middle management when we had three employees. At this point, I realized that I could no longer handle the further development of the product and, at the same time, be responsible for the financials, sales, personnel management and accounting."

Furthermore, middle management also affects the way in which information from "rank and file" employees, such as requests or feedback on new materials or equipment from suppliers or customers, becomes available to founders. Delegation to middle management makes more information on the status of current operations available to the founders, in turn reducing the likelihood that the founders will waste time evaluating current operations without potential for improvement (Gifford, 1992). Founders may even delegate decision making responsibility to middle managers to improve current operations, allowing them to continue searching, screening, and 
implementing new projects (Gifford, 1992). In other words, middle management decreases the founders' opportunity costs of not attending to innovation. In an interview, the middle manager of a software startup describes this mechanism in his startup:

"Our founders meet with the middle managers every week to receive updates and to discuss the status of current projects. That definitely helps the founders to concentrate on new projects, new features, and solutions they would like to launch on the market." In conclusion, we suggest that a startup's middle management is likely to improve its ability to innovate. Our first hypothesis states:

Hypothesis 1: Startups with middle management are more likely to introduce product innovations.

Moderating effects from opportunity costs for entrepreneurial attention to innovation The logic underlying hypothesis 1 is not directly testable since the shift of founder attention is not immediately observable. We rely instead on a contingency analysis that tests two situations in which the startup is particularly likely to benefit from founder attention to innovation and develop moderator hypotheses based on the pre-existing knowledge of founders and the opportunities for knowledge search in a startup's industry.

We focus first on the founders' prior technological knowledge base and argue that the larger the founders' knowledge base the greater are opportunity costs for the startup if founders cannot dedicate entrepreneurial attention to innovation. Extant literature frequently highlights that startups - through their founders - are differentially endowed with resources upon market entry, including prior technological knowledge, invested capital, or managerial, entrepreneurial, and industry experience (e.g., Shane, 2000; Dencker \& Gruber, 2015).

Prior knowledge has frequently been characterized as a central determinant of a firm's abil- 
ity to innovate (Rosenkopf \& Nerkar, 2001; Katila \& Ahuja, 2002). Dedicating attention decreases the likelihood of errors and false starts when using the same set of knowledge repeatedly, causing the search to become more reliable (Levinthal \& March, 1993). Moreover, the startup's search becomes more predictable if founders with prior knowledge have a better understanding of the requirements that need to be met for successful innovation (Li et al., 2013). At the same time, prior knowledge enables founders to better screen and evaluate new knowledge and recombinations of knowledge since prior knowledge is connected to the founders' absorptive capacity (Cohen \& Levinthal, 1990). In an interview, the middle manager in charge of investor relations for a pharmaceutical startup describes this mechanism in relation to the founder of her startup:

"Our founder is a scientist who had the initial patent and is still an active researcher for the company. Sometimes he has a hard time seeing what direction the firm is growing in. Then again, he understands that he has a scientific mindset, not a business school one."

As a result, startups are more innovative if founders with large stocks of existing knowledge can allocate sufficient attention to decision making on search, screening, and implementation. In this situation, middle management is most effective because it frees up the entrepreneurial attention of these founders. In sum, our second hypothesis states:

Hypothesis 2: Startups with middle management are more likely to introduce product innovations, and this likelihood increases with the size of the founders' existing knowledge base.

The second moderating effect that we focus on is the innovation opportunities in a startup's industry, suggesting that, as for the previous hypothesis, larger innovation opportunities increase 
the startups opportunity costs if founders cannot dedicate attention to innovation.

Gifford (1992) points out that the positive effect of founder attention on startup innovation is not limited to sources within the firm. The external environment is an important determinant for the search stages of the innovation processes (Koput, 1997). It determines the quality and quantity of useful knowledge and information that can enter a startup's innovation process. Founders are an important interface for external knowledge (Gifford, 1992).

The idea that innovation opportunities are largely determined by the industry in which a firm operates has been foundational to innovation research (e.g., Pavitt, 1984; Castellacci, 2008; Köhler et al., 2012). Industries differ significantly in the extent to which they can provide such opportunities to firms, depending, for example, on the pace of technology development, the emergence of new technologies, and the specific patterns of innovation in an industry (Nelson \& Winter, 1982).

Industries in which innovation opportunities are plentiful encourage extensive investments in searches, which, in turn, require individual firms to search more actively to access critical knowledge sources (Klevorick et al., 1995). This implies that industries with high innovation opportunities require a higher degree of attention from the founders to search for new knowledge effectively. The more entrepreneurial attention founders can make available for searching in high opportunity industries, the higher the likely rewards will be. In an interview, the founder of a high-tech startup describes the kind of attention he needs to devote to innovation opportunities in his industry:

"A major source of innovative ideas is customers. Then, I always keep myself informed about competitors. I read up on what's new on the market. I track new technological developments and business models. It's also important for me to stay on top of 
political developments on solar power payment schemes all over the globe."

Middle management that frees up entrepreneurial attention of this kind can therefore be expected to facilitate innovation outcomes, in particular for startups in industries with many innovation opportunities. Our third hypothesis states:

Hypothesis 3: Startups with middle management are more likely to introduce product innovations, and this likelihood increases with the innovation opportunities in the startup's industry.

\section{DATA AND METHODS}

Data

To test our hypotheses, we construct a dedicated dataset combining multiple data sources that is based on a linked employer-employee panel dataset that matches firm-level data from the KfW/ZEW Startup Panel, with the official employment statistics provided by the German Federal Employment Agency. The KfW/ZEW Startup Panel is a survey of German startups of 20052012 cohorts. It was established in 2008 as a joint project of the KfW Bankengruppe (Germany's largest state-owned promotional bank), the Centre for European Economic Research (ZEW), and Creditreform (Germany's largest credit rating agency). The KfW/ZEW Startup Panel is a stratified random sample of legally independent new ventures drawn from the Mannheim Enterprise Panel, which contains basic startup information (for a detailed description, see Bersch et al., 2014). Stratification is controlled for by including dummy variables for the stratification cells in all regressions. When included in the sample, firms cannot be older than three years, subsidiaries or ventures that resulted from merger activities are excluded (for a detailed description, see Fryges et al., 2010).

Startups that have participated in the survey once are subsequently followed for up to seven 
successive years. Data are collected using computer-assisted telephone interviews. In the present study, the survey data provide information about the founders' characteristics (i.e., educational background and managerial and entrepreneurial leadership experience) and venture characteristics (including innovation and R\&D activities).

We match the firm level information with employee level information from official Federal Employment Agency employment statistics. The employment statistics contain person-specific registry data on all employees subject to social security contributions in Germany. ${ }^{2}$ This dataset is a rich source of employee records, allowing, most importantly, the identification of middle managers based on occupation codes (see variable description below). Moreover, the employment statistics also provide details on additional employee characteristics for the purpose of our study.

As there is no common identifier in the two datasets, we match startups from the KfW/ZEW Startup Panel by means of a text search algorithm using startup names and addresses. Described in detail in Czarnitzki et al. (2015), the text search algorithm has proven to deliver very reliable results in various settings. We were able to match about $90 \%$ of the startups from the KfW/ZEW Startup Panel that self-reported having employees subject to social security contributions (during a telephone interview) with one or more establishments from the official employment statistics. Firms that self-reported having employees subject to social security contributions, but which could not be found in the official employment statistics, were removed from the sample.

We are able to draw on 5,672 observations from 2,431 startups that operate in knowledge-

\footnotetext{
${ }^{2}$ In addition to regular full-time and part-time employees, this includes apprentices, interns, and marginally employed personnel. All notifications on employment and unemployment spells of an individual can be linked with the aid of a unique person-specific identifier, making it possible to obtain the complete employment history of each employee. A further identifier makes it possible to match the employees to establishments.
} 
intensive industries, have at least one owner who is active in managing the firm, and have at least one paid employee in the panel dataset that we use for estimations. ${ }^{3} 4,785$ of these firm-year observations are from 1,544 startups that we observe at least twice; 887 startups are only observed once.

Variables

\section{Dependent variable}

Our hypotheses predict the likelihood with which startups introduce product innovations. Accordingly, we create a dummy variable for the introduction of a new product in a given year. ${ }^{4}$ The respective question in the questionnaire explicitly includes the introduction of new services (as the "products" of service firms). New products (or services) can have various degrees of novelty. The formulation of the question about innovation outcomes follows the OECD Oslo Manual on how to measure innovation (OECD, 2005) and is widely applied in the European "Community Innovation Surveys”. Accordingly, we identify a startup as having a product innovation when it indicates that it had a new product (or service) that is new to the market, not just new to the startup itself. We assess the robustness of our results by using all new-to-the-firm innovations and total factor productivity as alternative outcome measures.

\section{Explanatory variables}

Our main variables of interest on the right-hand side of our estimation equation are whether or not a firm employs at least one employee who is appointed with delegated decision-making authority (middle manager), the size of the existing knowledge stock of the founder and the extent

\footnotetext{
${ }^{3}$ Knowledge-intensive industries include cutting-edge and high-technology manufacturing, technology-intensive services, software supply and consultancy, and skill-intensive services in line with Fryges et al. (2010).

${ }^{4}$ The information on innovation in the data is only available in a yes/no format. It is not possible to differentiate firms with more than one innovation. Since the introduction of a new-to-the-market innovation is a rather rare event for a typical startup, a binary indicator for innovation outcomes should provide an adequate picture, however.
} 
of innovation opportunities in a startup's industry.

We construct our binary indicator for the presence of a middle manager from occupation codes available in the employment statistics of the German Federal Employment Agency. In the individual level data, occupations are coded using the five-digit occupation code KldB2010 (the German adaption of ISCO-08, devised by the Federal Employment Agency). While the first three digits describe the particular functional specialization of an occupation, individuals in occupations with supervisory or executive competences are identified by a "9" as the fourth digit of the five-digit KldB2010 occupation code. We classify individuals with such supervisory or executive competences as middle managers. We use a binary indictor, since almost $80 \%$ of the startups with middle management have only a single middle manager.

In post-hoc analyses, we differentiate between middle managers in technical occupations and middle managers in administrative occupations. ${ }^{5}$ Since our definition of middle management would also include professional managers that were hired to replace founders, we restrict our sample to firm-year observations for which there is at least one owner active in managing the firm. We argue that in such situations the owner-manager is usually the ultimate decision maker in the firm. We test this definition in two robustness checks. First, we further restrict our sample to firm-year observations before the first change (if any) in the team of owner-managers occurs, so that the owner-managers are necessarily founders of the company. This eliminates the risk that we would classify a professional CEO, who also becomes (co-)owner of a business and replaces the founders as ultimate decision makers, as "middle manager". In a second robustness check, we exclude all middle managers whose occupation codes refer to CEO positions. This

\footnotetext{
${ }^{5}$ We use a classification of technical jobs developed by the German Federal Employment Agency and a similar, adapted classification for administrative jobs for the purpose of the robustness check.
} 
might be overly restrictive, because it excludes managers who in fact take middle positions between founders and rank-and-file employees.

We approximate the founders' existing knowledge base by the number of patents the founders of a startup held prior to the registration of the firm. This information is retrieved from the survey data of the KfW/ZEW Startup Panel.

We measure the innovation opportunities in the startup's industry by the average number of different innovation sources that firms in the same two-digit NACE industry use in the innovation process. The measure follows the idea that external sources of innovation provide knowledge and impulses that firms can benefit from in their innovation activities (Laursen \& Salter, 2006). We derive this information from Mannheim Innovation Panel firm level data, the German contribution to the harmonized European "Community Innovation Survey”. It covers ten different information sources, such as customers, suppliers, competitors, and universities. We sum up the number of different innovation sources that firms have used to yield a measure of breadth. Subsequently, we calculate the average breadth in each two-digit NACE industry. ${ }^{6}$

We control for a number of factors that have frequently been shown to be associated with the likelihood to innovate (Ahuja et al., 2008). Table A.1 in the online appendix provides details on the construction of all variables. We control for the number of founders and for R\&D in particular, by including R\&D expenditures (scaled by startup sales). In addition, we control for the size of the startup measured by the number of dependent employees (including middle managers). We account for differences in human capital quality using a dummy variable if at least one of the founders had a tertiary education as well as the share of employees with tertiary education.

\footnotetext{
${ }^{6}$ To obtain a meaningful number of observations for each two-digit NACE industry, we pool data from the Mannheim Innovation Panel waves of 2005 and 2009 for the first half of our observation period (2007-2009) and data from the waves of 2013 and 2017 for the second half of our observation period (2010-2012)
} 
We use a dummy variable for the founders' tertiary education since the information is only available in the dataset as yes/no information. Employees' levels of education can be calculated as shares from the German Federal Employment Agency registry data. As a result, we decided to use the more precise information available for employees.

Moreover, founder experience has been found to impact startup performance (Colombo et al., 2004; Colombo \& Grilli, 2005). We capture these effects with two dummy variables indicating whether the founder had managerial or entrepreneurial experience as well as the number of years of industry experience of the founder. Moreover, some founders have been found to be reluctant to take on management tasks (Boeker \& Karichalil, 2002). Hence, we include a dummy variable for whether at least one of the founders has an educational background in business administration (or economics) and the share of employees in administrative occupations (excluding middle managers) at the time of firm foundation.

Taking into consideration structural differences among startups, we control for the startup's age and whether it is incorporated (limited liability). In addition, following Dencker and Gruber (2015), we include a measure of the riskiness of a startup's business opportunity since it might affect both the organizational design choices and innovation potential. We further add industry dummies on the three-digit NACE level, as well as year dummies to all specifications. Estimation approach and identification Since our dependent variable is binary, we choose probit estimates with standard errors robust to clustering at the startup level as our main estimation method. In our analyses, we estimate a series of interaction effects. The interpretation of interaction effects in nonlinear models, such as probit or logit models, is not straightforward (Ai \& Norton, 2003; Greene, 2010). Therefore, we initially calculate the correct marginal effects manually for the interaction terms using the con- 
trast operator of Stata's "margins" command. In addition, we double check all results with linear probability models as a robustness check and do not find any qualitative differences.

Endogeneity is a potential issue in our empirical setting. A first source of endogeneity might stem from simultaneity/omitted variable bias. It seems plausible to assume that startups of higher quality might simultaneously have a higher probability of doing both, hiring a middle manager and introducing an innovation. If we cannot control for startup quality adequately, we might spuriously attribute changes in innovation propensity to the introduction of middle management. We address this problem using a two-step strategy. First, we pre-balance our sample over a large number of indicators for firm quality with respect to firm-year observations with middle management and those without. Second, we control for factors that might determine the firms' innovation success directly in all estimated models.

We apply entropy balancing to implement the pre-balancing empirically. Entropy balancing achieves balance over specified moments of selected covariates by deriving sample weights. The retrieved weights are then used in subsequent weighted estimations (Hainmueller, 2011; Hainmueller \& Xu, 2013). Intuitively, this can be understood as the creation of a synthetic control group, where the observations in the control group are reweighted so that their specified sample moments mimic those of the treatment group as closely as possible (cf. Abadie et al., 2010). In contrast to other related methods, for instance propensity score matching, entropy balancing induces covariate balance directly, and not as the result of a propensity score matching procedure (which requires iterated re-specifications of the propensity score estimation to achieve covariate balance). Entropy balancing has been applied for sample balancing in several recent studies (e.g., Bansak et al., 2016; Malesky \& Taussig, 2017; Satyanath et al., 2017).

Our choice of indicators for startup quality in the balancing exercise follows the results of 
Colombo and Grilli (2013), who analyze the antecedents of the emergence of a middle management layer in Italian high-tech startups. Moreover, we balance on additional factors that significantly predict the existence of a middle management in our data to ensure a balanced regression sample. We balance on the number of employees of the startup, whether the firm is incorporated with limited liability, firm age, the riskiness of a startup's business opportunity, whether the firm reported having equity investors in the first interview, the number of patents a firm founder held at the time of firm foundation, the R\&D intensity of the startup, a dummy variables for whether at least one founder has an education in business administration/economics, the share of employees with administrative occupations at the time of foundation, measures for founder human capital (whether the founder has a tertiary education, whether the founder had started a firm before, and whether the founder has experience as a manager in dependent employment), the employees' human capital (the share of employees with tertiary education), and the stratification industries of the KfW/ZEW Startup Panel. ${ }^{7}$

As expected, the data show that startups with middle management clearly outperform those without middle management with respect to nearly all firm quality indicators. After balancing, though, original differences are leveled entirely (see Table A.2 in the online appendix for results). As a robustness check, we estimate fixed effects regressions that allow us to control for unobserved time-constant heterogeneity between startups.

A second, closely related, source of endogeneity might arise from direct reverse causality when firms appoint a middle manager in response to the introduction of a market novelty. We double check our results by using lagged values of middle management and other innovation inputs as explanatory variables to assess the potential bias caused. To assess the robustness of

\footnotetext{
${ }^{7}$ For founding teams, we use information on the founder with the highest education/most experience.
} 
our identification strategy, we re-estimate our main models by an endogenous treatment effects model, sometimes also referred to as a binary endogenous-variable model. The intuition behind this Heckman-type model is to introduce exogenous variation in the probability to employ a middle manager via exclusion restrictions in a (first) selection stage and to estimate unbiased effects in the second stage by controlling for the probability of selection (Heckman, 1978). As exclusion restrictions in the first stage of the endogenous treatment effects model (selection equation), we use two measures that predict the presence of a middle manager but that we regard as plausibly exogenous to a startup's innovation performance: (1) the number of executives in firms that filed bankruptcy in the same district and one-digit NACE industry in a given year and (2) the propensity that other firms in the sample, which operate in the same one-digit NACE industry and are in the same size category, have middle management. ${ }^{8}$ The first exclusion restriction introduces exogenous variation due to a local supply shock of potential candidates for middle management positions. The second exclusion restriction introduces exogenous variation in the firms' demand for middle managers.

\section{RESULTS}

Descriptive statistics

Tables 1 and 2 provide summary statistics, pairwise correlations and variance inflation factors (VIFs). The descriptive statistics show that $15 \%$ of startups in our sample report product innovations, which gives some indication that achieving innovation success is challenging for the average high-tech startup. On average, startups are 3.04 years old, have 1.69 founders, and employ

\footnotetext{
${ }^{8}$ The necessity to introduce a hierarchical structure depends crucially on industry and firm size (Rajan \& Zingales, 2001). However, the probability that other firms employ a middle manager should not directly influence a focal firm's probability to launch an innovation. We define six size categories to achieve an as uniform as possible distribution of observations over size categories: (1) 1 employee, (2) 2 employees, (3) 3 or 4 employees, (4) 5 to 7 employees, (5) 8 to 14 employees, and (6) more than 14 employees.
} 
4.79 employees. They spend $12 \%$ of sales on R\&D. Founders hold, on average, 0.4 patents when creating the startup, albeit with a large standard deviation. As an indicator of innovation opportunities, firms in the startup's industry use, on average, 4.87 different innovation sources (with a 2.03 to 7.37 range).

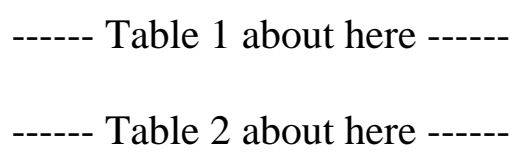

Most of the startups operate in service sectors, especially technology-intensive services (41\%). 31 percent of the startups operate in high-tech manufacturing sectors, which typically have higher entry barriers, for example, due to necessary fixed capital investments. The riskiness of the business opportunities of startups in our sample is at an intermediate level at 315.51 on a scale between 100 and 600. Most startups are incorporated as limited liability companies (65\%) but few have equity investors from the start (4\%). Moreover, $11 \%$ of startups in our sample have middle management. Hence, a large number of startups makes this organizational design choice, but the majority of startups does not. This indicates that the introduction of middle management has the potential to be a strategic decision differentiating startups from their peers.

None of the correlations between the explanatory variables reach levels that indicate collinearity problems. This is supported by the Variance Inflation Factors (VIF) between the main explanatory variables, which has an average value of 1.15 and a maximum value of 1.30 . The VIF is far below the usually applied critical level of 10 (Belsley et al., 1980). Exploratory study on the determinants of the introduction of middle management We explore the determinants for the introduction of middle management in a startup further by estimating a probit model for the presence of this organizational level. Table 3 shows the estimation results as model A. 
------ Table 3 about here ------

Most importantly, startup size (number of employees) is positively and significantly related to the likelihood of startups to employ middle managers. Firm size is likely to increase the information volume in startups as well as coordination and management needs. The same factors may also explain the significant, positive relationship of the share of employees with tertiary education. Presumably, these skilled employees engage in increasingly complex and interconnected tasks. The legal form (limited liability) and the investor structure of the startup (equity investors) are also positively associated with the likelihood of startups to employ middle management. These factors may indicate increasing maturity and professionalization of a focal startup. Interestingly, conditional on other covariates, the age of the startup has a negative, significant (10\% level of statistical significance) relationship with the employment of middle management. This finding suggests that middle management levels are not an automatic byproduct of startups maturing over time but are driven much more by other startup factors, such as firm size.

In terms of founder characteristics, startups are significantly more likely to introduce middle management when founders have managerial experience or an education in business administration/economics but comparatively few patents. Hence, founders with managerial, instead of technological backgrounds, appear to be able to foresee monitoring and coordination needs that middle managers can take over.

In model B of Table 3, we repeat the same probit estimation but apply the weights derived from entropy balancing. All variables that significantly predict the presence of a middle management level in model A no longer have significant effects in the weighted model. As intended, the entropy balancing approach eliminates potential selection biases in subsequent estimations by achieving balance between startups that introduced middle management and the control group. 
Results of hypothesis testing

In line with hypothesis 1 , our main multivariate regression estimates from weighted probit models reveal a significant and positive relationship between middle management and a startup's likelihood to introduce a product innovation (Table 4, column A; see Table A.3 in the online appendix, column A for results from the unbalanced/non-weighted model). Employing at least one middle manager increases the likelihood to introduce a product innovation by 4.3 percentage points. Given that the average propensity to introduce a product innovation in the sample is $15 \%$, this effect size stands for a substantial increase.

------ Table 4 about here ------

The marginal effects of the wide range of included control variables show the expected signs. Most noteworthy, the R\&D intensity has a positive and significant effect, as does the size of the existing knowledge stock (patents at time of foundation), the extent of innovation opportunities in the industry of the startup (average breadth of innovation sources of firms in the same NACE2 industry), whether at least one of the founders has a tertiary education, and the share of employees with tertiary education.

We apply interaction analyses to test the moderating effects on the relationship between middle management and innovation performance that we proposed in hypotheses 2 and 3 (Table 4, columns B-D). In support of hypothesis 2 , we find a positive and significant interaction effect between the presence of a middle management level and a startup's existing knowledge stock. Our data also support hypothesis 3, indicating a positive and significant interaction effect between the availability of innovation opportunities in a startup's industry and the presence of middle management. 


\section{Robustness checks}

We conduct a number of consistency check estimations (for the main robustness checks, see Table A.3 in the online appendix, columns B-E; all other estimation tables are available from the authors upon request). First, we estimate fixed effects model and models with lagged values for middle management and other innovation inputs as explanatory variables, the estimated effect of middle management remains significant and quantitatively stable. Second, we apply an endogenous treatment effects model. Both exclusion restrictions have a positive and statistically significant impact on the probability to employ a middle manager in the first stage of the estimation procedure. Again, the marginal effect of middle management in the second stage of the estimation remains significant and of comparable size. Third, we re-estimate the balanced main model using alternative operationalizations of successful innovation as dependent variables. We find very similar results qualitatively when we assess the effects of middle management on new-tothe-firm innovations (instead of new-to-the market innovations) and total factor productivity. To estimate effects on total factor productivity, we estimate value-added production functions.

Overall, we take the stable results of the robustness checks as evidence for the reliability of the presented results.

As additional consistency checks, we examine the robustness of our results with respect to our empirical definition of middle management. In a first step, we exclude all observations of businesses after the first change (if any) to the initial team of owner-managers is reported. In a second step, we exclude all individuals whose occupation classifications refer to CEO positions. In both cases, the effect of middle management remains stable, which leads us to the conclusion that the reported effects stem from middle managers in firms in which the founders are the ultimate decision makers. 
Finally, we explore heterogeneity among middle managers by separating them into middle managers in technical and administrative occupations to provide a more nuanced understanding of their effects on innovation. In line with our theoretical reasoning, the estimation results suggest that the positive significant effect on product innovation emerges for middle managers with administrative occupations, while middle managers with technical occupations have no significant effects.

\section{DISCUSSION}

Our research addresses an important gap in the literature on organizational design. While prior research has studied adjustments in startups' organizational design through a process of professionalization (Greiner, 1972; Hellmann \& Puri, 2002), i.e. the replacement of founders through professional managers once a startup reaches a certain threshold (e.g., Daily \& Dalton, 1992; Gedajlovic et al., 2004; Walters et al., 2010), relatively little is known about startup professionalization that concerns the introduction of an additional hierarchical level during the startup phase and when founders are still the ultimate decision makers. Hierarchical differentiation, such as middle management, has been characterized as a crucial step for startups to professionalize their business (Colombo \& Grilli, 2013), yet the implications for innovation, arguably one of the most important strategic objectives of high-tech startups, have not been documented in the theoretical and empirical literature on professionalization.

We address this gap theoretically by integrating mechanisms from the opportunity costs for founder attention allocation (Gifford, 1992) into an innovation model (Koput, 1997). Within our logic, middle management can help founders to direct comparatively more attention to innovation. Consistent with this theoretical reasoning, our empirical analyses provide a number of compelling findings for innovation outcomes in high-tech startups. Based on a unique sample of 
2,431 startups in Germany, we find that high-tech startups with middle management have a higher likelihood of introducing product innovations. We attribute this finding to the fact that the establishment of middle management frees up founder attention for innovation by increasing information processing and monitoring capacity in the startup (Colombo \& Grilli, 2013). Since the allocation of founder attention is not directly observable, we rely on a contingency analysis of moderating conditions under which additional attention to startup innovation is particularly beneficial. Our results emphasize that foregone opportunities for successful innovation significantly moderate the middle management effect: Startup innovation benefits most from additional founder attention through middle management when (a) founders have pre-existing knowledge and when (b) startups operate in industries that provide many opportunities for innovation.

Our findings advance academic research along two dimensions. First, existing entrepreneurship literature emphasizes how startups mature and professionalize through their organizational design choices (Baron et al., 1999; Colombo \& Grilli, 2013; Hellmann \& Puri, 2002). Our theoretical model focusses on one particular organizational design choice, i.e., the establishment of a middle management layer in a startup, and links it to innovation performance, arguably one of the most crucial strategic outcomes for high-tech startups (Block et al., 2016). We delineate this design choice from other forms of professionalization such as the replacement of founders by professional managers and find that the introduction of middle management can occur much earlier in the organizational lifecycle than thresholds for professionalization found in the literature may suggest (Daily \& Dalton, 1992; Walters et al., 2010). We integrate mechanisms on information processing and monitoring from existing middle management literature into founder attention and innovation models. On the one hand, this provides a basis for future studies to theorize about how middle management affects a startup's other strategic outcomes, e.g., internation- 
alization. On the other hand, it highlights a weakness in existing literature investigating the innovation outcomes of high-tech startups. Studies ignoring the hierarchical levels are likely to suffer from biased results.

Second, while entrepreneurial experience and opportunity are important mechanisms in entrepreneurship research (e.g., Dencker \& Gruber, 2015), we know comparatively little about how startups set up organizational designs to increase the payoffs of these experiences and opportunities. Within our theoretical model, founder attention is a scarce resource for startups to achieve innovation, and startups can actively influence its availability through hierarchical differentiation of decision making using middle management. We demonstrate this insight and its theoretical relevance in a contingency analysis that incorporates factors emerging from both founder experience and industry opportunity. Our theoretical reasoning can serve as a platform for theorizing about other organization design choices that affect the ability of startups to exploit various types of founder experiences and external opportunities. In that sense, our study complements recent research on the complementarities in the skills between founders and their early employees (Müller \& Murmann, 2016).

Apart from these academic contributions, our findings have relevance for decision making in startups. We provide evidence of the innovation benefits of middle management for startups and outline conditions under which the establishment of a middle management level is most effective. In high-tech startups that have founders with rich knowledge bases and that operate in industries with many innovation opportunities, founders should critically question their own attention capacities and to what extent they can dedicate attention to innovation. Similarly, startup advisors, such as investors, consultants, and government agencies, should take these mechanisms into account. We show that the likelihood for the innovation success of a startup includes organi- 
zational design choices that will make it more likely that the startup will have suitable information processing and monitoring capacities in place to arrive at promising R\&D decisions. LIMITATIONS AND FUTURE RESEARCH

While we employ careful econometric analyses to substantiate the benefits of middle management for startup innovation, our research is not without limitations. First, the startups in our sample have about five dependent employees on average. On the one hand, these startups may appear small for examining an organizational design choice such as the establishment of a middle management level. On the other hand, our qualitative interview evidence indicates that founders consider middle management to become salient with even fewer employees. Together with the rather young age of the startups in our sample (three years on average with a maximum of eight years), our research provides a view on the early stage in the organizational lifecycle of startups. Nevertheless, we suspect that an analysis based on relatively larger startups could provide interesting and complementary evidence on the mechanisms invoked here.

Second, our research investigates only one individual organizational design choice and seeks to isolate its effect on innovation. While we control for whether founders were replaced by professional managers, we do not study the effects that such professionalization in combination with middle management may have on innovation. Moreover, the organizational structure of startups can be characterized by several other dimensions that may interact with the establishment of a middle management level. Future research could therefore consider professionalization and other design choices and study their interrelationships with middle management.

Third, while our research design allows us to capture the effect of middle management across a number of startups and industries, smaller scale and/or qualitative studies may be better positioned to delineate communication and coordination patterns by which middle managers and 
founders interact and how the relationship between the founders and rank-and-file employees changes. Such studies would also be particularly suited to further explore heterogeneity among middle managers, e.g., their job tasks, experience, or recruiting, and how these influence communication and coordination with founders.

Finally, our research also needs to acknowledge limitations to the empirical analysis. While both the entropy balancing and the endogenous treatment effects model approach using exclusion restrictions provide no indication regarding reverse causality or simultaneity, we cannot fully rule out that startups only hire middle managers and benefit from the introduction of middle management when they expect the introduction of a new product or service. Future research could either try to identify other exogenous shocks or attempt to establish causal evidence in experimental settings.

\section{CONCLUSION}

We have argued theoretically and shown empirically that startups with a middle management layer have a higher likelihood to introduce product innovations than startups without middle management. Within our reasoning, the positive effects of middle management arise through improved allocation of founder attention for innovation, one of the most important strategic objectives of high-tech startups. We document the importance of middle management in the early stages of the organizational lifecycle and find that there are conditions under which some startups are better at capitalizing on this design choice: when founders are particularly well endowed with technological knowledge and when there are many innovation opportunities in the startup's industry. In sum, our research outlines new opportunities for theorizing and subsequent empirical analyses in the crucial startup phase of new high-tech ventures in which they are hard pressed to generate innovation before funding runs out. 


\section{REFERENCES}

Abadie A, Diamond A, Hainmueller J. 2010. Synthetic Control Methods for Comparative Case Studies: Estimating the Effect of California's Tobacco Control Program. Journal of the American Statistical Association 105(490): 493-505.

Acs ZJ, Gifford S. 1996. Innovation of Entrepreneurial Firms. Small Business Economics 8: 203218.

Ahlin B, Drnovsek M, Hisrich RD. 2014. Entrepreneurs' Creativity and Firm Innovation: The Moderating Role of Entrepreneurial Self-Efficacy. Small Business Economics 43: 101-117.

Ahuja G, Lampert CM, Tandon V. 2008. Moving Beyond Schumpeter: Management Research on the Determinants of Technological Innovation. Academy of Management Annals 2: 1 98.

Ai C, Norton EC. 2003. Interaction Terms in Logit and Probit Models. Economics Letters 80: 123-129.

Amit R, Glosten L, Muller E. 1990. Entrepreneurial Ability, Venture Investments, and Risk Sharing. Management Science 36(10): 1232-1245.

Bansak K, Hainmueller J, Hangartner D. 2016. How Economic, Humanitarian, and Religious Concerns Shape European Attitudes toward Asylum Seekers. Science 354(6309): 217-222.

Baron JN, Burton MD, Hannan MT. 1999. Engineering Bureaucracy: The Genesis of Formal Policies, Positions, and Structures in High-Technology Firms. Journal of Law, Economics and Organization 15(1): 1-41.

Belsley DA, Kuh E, Welsh RE. 1980. Regression Diagnostics: Identifying Influential Data and Sources of Collinearity: New York.

Bersch J, Gottschalk S, Müller B, Niefert M. 2014. The Mannheim Enterprise Panel (Mup) and Firm Statistics for Germany. . In ZEW Centre for European Economic Research Discussion Paper.

Block JH, Fisch CO, van Praag M. 2016. The Schumpeterian Entrepreneur: A Review of the Empirical Evidence on the Antecedents, Behaviour and Consequences of Innovative Entrepreneurship. Industry and Innovation 24(1): 61-95.

Boeker W, Karichalil R. 2002. Entrepreneurial Transitions: Factors Influencing Founder Departure. Academy of Management Journal 45(4): 818-826.

Castellacci F. 2008. Technological Paradigms, Regimes and Trajectories: Manufacturing and Service Industries in a New Taxonomy of Sectoral Patterns of Innovation. Research Policy 37(6-7): 978-994.

Cohen WM, Levinthal DA. 1990. Absorptive Capacity: A New Perspective on Learning and Innovation. Administrative Science Quarterly 35(1): 128-153.

Colombo MG, Delmastro M, Grilli L. 2004. Entrepreneurs' Human Capital and the Start-up Size of New Technology-Based Firms. International Journal of Industrial Organization 22(8): 1183-1211.

Colombo MG, Grilli L. 2005. Founders' Human Capital and the Growth of New TechnologyBased Firms: A Competence-Based View. Research Policy 34(6): 795-816.

Colombo MG, Grilli L. 2013. The Creation of a Middle-Management Level by Entrepreneurial Ventures: Testing Economic Theories of Organizational Design. Journal of Economics and Management Strategy 22(2): 390-422.

Czarnitzki D, Doherr T, Hussinger K, Schliessler P, Toole AA. 2015. Individual Versus Institutional Ownership of University-Discovered Inventions. In ZEW Centre for European Economic Research Discussion Paper. 
Dahlander L, O'Mahony S, Gann DM. 2016. One Foot in, One Foot Out: How Does Individuals' External Search Breadth Affect Innovation Outcomes? Strategic Management Journal 37(2): 280-302.

Daily CM, Dalton DR. 1992. Financial Performance of Founder-Managed Versus Professionally Managed Small Corporations. Journal of small business management 30(2): 25-34.

Dencker JC, Gruber M. 2015. The Effects of Opportunities and Founder Experience on New Firm Performance. Strategic Management Journal 36(7): 1035-1052.

Fryges H, Gottschalk S, Kohn K. 2010. The Kfw/Zew Start-up Panel: Design and Research Potential. Journal of Applied Social Science Studies (European Data Watch) 130: 117-131.

Garicano L. 2000. Hierarchies and the Organization of Knowledge in Production. Journal of Political Economy 108(5): 874-904.

Gedajlovic E, Lubatkin MH, Schulze WS. 2004. Crossing the Threshold from Founder Management to Professional Management: A Governance Perspective. Journal of Management Studies 41(5): 899-912.

Gifford S. 1992. Allocation of Entrepreneurial Attention. Journal of Economic Behavior \& Organization 19(3): 265-284.

Greene WH. 2010. Testing Hypotheses About Interaction Terms in Nonlinear Models. Economics Letter 107(2): 291-296.

Greiner LE. 1972. Evolution and Revolution as Organizations Grow. Harvard Business Review 50(3): 37-46.

Hainmueller J. 2011. Entropy Balancing for Causal Effects: A Multivariate Reweighting Method to Produce Balanced Samples in Observational Studies. Political Analysis 20(1): 25-46.

Hainmueller J, Xu Y. 2013. Ebalance: A Stata Package for Entropy Balancing. Journal of Statistical Software 54(7).

Harris M, Raviv A. 2002. Organization Design. Management Science 48(7): 852-865.

Heckman JJ. 1978. Dummy Endogenous Variables in a Simultaneous Equation System. Econometrica 46(4): 931-959.

Hellmann T, Puri M. 2002. Venture Capital and the Professionalization of Start-up Firms: Empirical Evidence. The Journal of Finance 57(1): 169-197.

Kaplan S. 2011. Research in Cognition and Strategy: Reflections on Two Decades of Progress and a Look to the Future. Journal of Management Studies 48(3): 665-695.

Katila R. 2002. New Product Search over Time: Past Ideas in Their Prime? Academy of Management Journal 45: 995-1010.

Katila R, Ahuja G. 2002. Something Old, Something New: A Longitudinal Study of Search Behavior and New Product Introduction. Academy of Management Journal 45(6): 11831194.

Klevorick AK, Levin RC, Nelson RR, Winter SG. 1995. On the Sources and Significance of Interindustry Differences in Technological Opportunities. Research Policy 24(2): 185-205.

Köhler C, Sofka W, Grimpe C. 2012. Selective Search, Sectoral Patterns, and the Impact on Product Innovation Performance. Research Policy 41(8): 1344-1356.

Koput KW. 1997. A Chaotic Model of Innovative Search: Some Answers, Many Questions. Organization Science 8(5): 528-542.

Laursen K, Salter A. 2006. Open for Innovation: The Role of Openness in Explaining Innovation Performance among U.K. Manufacturing Firms. Strategic Management Journal 27: 131150. 
Levinthal DA, March JG. 1993. The Myopia of Learning. Strategic Management Journal 14: $95-$ 112.

Li Q, Maggitti PG, Smith KG, Tesluk PE, Katila R. 2013. Top Management Attention to Innovation: The Role of Search Selection and Intensity in New Product Introductions. Academy of Management Journal 56(3): 893-916.

Malesky E, Taussig M. 2017. The Danger of Not Listening to Firms: Government Responsiveness and the Goal of Regulatory Compliance. Academy of Management Journal 60(5): 1741-1770.

Marvel MR, Lumpkin GT. 2007. Technology Entrepreneurs' Human Capital and Its Effects on Innovation Radicalness. Entrepreneurship Theory and Practice 31(6): 807-828.

Müller B, Murmann M. 2016. The Workforce Composition of Young Firms and Product Innovation - Complementarities in the Skills of Founders and Their Early Employees. In ZEW Discussion Paper. Mannheim.

Nelson RR, Winter SG. 1982. An Evolutionary Theory of Economic Change. Harvard University Press: Cambridge, MA.

Nelson T. 2003. The Persistence of Founder Influence: Management, Ownership, and Performance Effects at Initial Public Offering. Strategic Management Journal 24(8): 707724.

Ocasio W. 1997. Towards an Attention-Based View of the Firm. Strategic Management Journal 18: $187-206$.

OECD. 2005. Oslo Manual: Guidelines for Collecting and Interpreting Innovation Data (3rd ed.). Organisation for Economic Co-operation and Development: Paris.

Pavitt K. 1984. Sectoral Patterns of Technical Change: Towards a Taxonomy and a Theory. Research Policy 13(6): 343-373.

Radner R. 1993. The Organization of Decentralized Information Processing. Econometrica 61(5): 1109-1146.

Rajan R, Wulf J. 2003. The Flattening Firm: Evidence from Panel Data on the Changing Nature of Corporate Hierarchies. National Bureau of Economic Research Working Paper Series No. 9633.

Rajan R, Zingales L. 2001. The Firm as a Dedicated Hierarchy: A Theory of the Origins and Growth of Firms. The Quarterly Journal of Economics 116(3): 805-851.

Rosenkopf L, Nerkar A. 2001. Beyond Local Search: Boundary-Spanning, Exploration, and Impact in the Optical Disc Industry. Strategic Management Journal 22(4): 287-306.

Satyanath S, Voigtländer N, Voth HJ. 2017. Bowling for Fascism: Social Capital and the Rise of the Nazi Party. Journal of Political Economy 125(2): 478-526.

Shane SA. 2000. Prior Knowledge and the Discovery of Entrepreneurial Opportunities. Organization Science 11(4): 448-469.

Simon HA. 1948. Administrative Behavior. A Study of Decision-Making in Administrative Organizations: New York.

Sine WD, Mitsuhashi H, Kirsch DA. 2006. Revisiting Burns and Stalker: Formal Structure and New Venture Performance in Emerging Economic Sectors. Academy of Management Journal 49(1): 121-132.

Van de Ven AH. 1986. Central Problems in the Management of Innovation. Management Science 32(5): 590-607. 
Venkataraman S. 1997. The Distinctive Domain of Entrepreneurship Research: An Editor's Perspective. In Advances in Entrepreneurship, Firm Emergence, and Growth. Katz JN, Brockhaus R (eds.), JAI Press: Greenwich.

Walters BA, Kroll M, Wright P. 2010. The Impact of Tmt Board Member Control and

Environment on Post-Ipo Performance. Academy of Management Journal 53(3): 572-595.

Wasserman N. 2012. The Founder's Dilemmas: Anticipating and Avoiding the Pitfalls That Can Sink a Startup. Princeton University Press: Princeton, NJ.

Wiklund J, Shepherd D. 2003. Aspiring for, and Achieving Growth: The Moderating Role of Resources and Opportunities. Journal of Management Studies 40(8): 1919-1941.

Wu CY-H, Hsu H-H. 2018. Founders and Board Structure: Evidence from Uk Ipo Firms. International Review of Financial Analysis 56(March): 19-31.

Zahra SA, Filatotchev I, Wright M. 2009. How Do Threshold Firms Sustain Corporate Entrepreneurship? The Role of Boards and Absorptive Capacity. Journal of Business Venturing 24(3): 248-260. 


\section{TABLES}

Table 1. Descriptive statistics

\begin{tabular}{|c|c|c|c|c|c|}
\hline \multirow[b]{2}{*}{ Variable } & \multirow[b]{2}{*}{ Unit } & \multicolumn{4}{|c|}{ All firms $(N=5,672)$} \\
\hline & & Mean & S.D. & Min & Max \\
\hline Product innovation $(\mathrm{y} / \mathrm{n})$ & $(y / n)$ & 0.15 & 0.36 & 0.00 & 1.00 \\
\hline Firm has middle management $(\mathrm{y} / \mathrm{n})$ & $(y / n)$ & 0.11 & 0.31 & 0.00 & 1.00 \\
\hline Innovation opportunities in NACE2 industry & Count & 4.87 & 1.01 & 2.03 & 7.37 \\
\hline Number of patents before foundation & Count & 0.40 & 6.27 & 0.00 & 180.00 \\
\hline Number of dependent employees & Count & 4.79 & 4.60 & 1.00 & 28.00 \\
\hline R\&D intensity (R\&D/sales) & Share & 0.12 & 0.34 & 0.00 & 2.00 \\
\hline Number of founders in team & Count & 1.69 & 0.96 & 1.00 & 9.00 \\
\hline Founder with tertiary education $(\mathrm{y} / \mathrm{n})$ & $(y / n)$ & 0.66 & 0.47 & 0.00 & 1.00 \\
\hline Founder has managerial experience (y/n) & $(y / n)$ & 0.51 & 0.50 & 0.00 & 1.00 \\
\hline Founder has entrepreneurial experience $(\mathrm{y} / \mathrm{n})$ & $(y / n)$ & 0.47 & 0.50 & 0.00 & 1.00 \\
\hline Founder's years of industry experience & Years & 18.48 & 9.23 & 1.00 & 50.00 \\
\hline Founder has administrative education $(\mathrm{y} / \mathrm{n})$ & $(y / n)$ & 0.24 & 0.43 & 0.00 & 1.00 \\
\hline Employees with admin. occupations (share) & Share & 0.16 & 0.33 & 0.00 & 1.00 \\
\hline Employees with tertiary education (share) & Share & 0.26 & 0.33 & 0.00 & 1.00 \\
\hline Equity capital in year of foundation $(y / n)$ & $(y / n)$ & 0.04 & 0.21 & 0.00 & 1.00 \\
\hline Limited liability $(y / n)$ & $(y / n)$ & 0.65 & 0.48 & 0.00 & 1.00 \\
\hline Firm age & Years & 3.04 & 1.76 & 0.08 & 8.00 \\
\hline Riskiness of business opportunity & Score & 315.51 & 32.90 & 239.00 & 600.00 \\
\hline High-technology manufacturing & $(y / n)$ & 0.31 & 0.46 & 0.00 & 1.00 \\
\hline Technology-intensive services & $(y / n)$ & 0.41 & 0.49 & 0.00 & 1.00 \\
\hline Software supply and consultancy & $(y / n)$ & 0.14 & 0.34 & 0.00 & 1.00 \\
\hline Skill-intensive services & $(y / n)$ & 0.14 & 0.35 & 0.00 & 1.00 \\
\hline Year 2007 & $(y / n)$ & 0.07 & 0.25 & 0.00 & 1.00 \\
\hline Year 2008 & $(y / n)$ & 0.15 & 0.36 & 0.00 & 1.00 \\
\hline Year 2009 & $(y / n)$ & 0.18 & 0.38 & 0.00 & 1.00 \\
\hline Year 2010 & $(y / n)$ & 0.19 & 0.39 & 0.00 & 1.00 \\
\hline Year 2011 & $(y / n)$ & 0.21 & 0.41 & 0.00 & 1.00 \\
\hline Year 2012 & $(\mathrm{y} / \mathrm{n})$ & 0.21 & 0.41 & 0.00 & 1.00 \\
\hline
\end{tabular}

Notes: Additional control variable: funding by KfW bank; S.D.: standard deviation; y/n: yes/no. 
Table 2. Pairwise correlations of dependent and main explanatory variables $(n=5,672)$

\begin{tabular}{|c|c|c|c|c|c|c|c|c|c|c|c|c|c|c|c|c|c|c|c|}
\hline & Variable & VIF & (1) & (2) & (3) & (4) & (5) & (6) & (7) & $(8)$ & (9) & (10) & $(11)$ & $(12)$ & $(13)$ & $(14)$ & $(15)$ & $(16)$ & (17) \\
\hline (1) & Product innovation $(\mathrm{y} / \mathrm{n})$ & & 1 & & & & & & & & & & & & & & & & \\
\hline (2) & Firm has middle management $(\mathrm{y} / \mathrm{n})$ & 1.00 & $0.12 *$ & 1 & & & & & & & & & & & & & & & \\
\hline (3) & Innovation opportunities in NACE2 industry & 1.13 & $0.18^{*}$ & $0.07 *$ & 1 & & & & & & & & & & & & & & \\
\hline (4) & Number of patents before foundation & 1.04 & $0.02 *$ & -0.01 & 0.02 & 1 & & & & & & & & & & & & & \\
\hline (5) & Number of dependent employees & 1.13 & $0.10^{*}$ & $0.27 *$ & $0.07 *$ & -0.02 & 1 & & & & & & & & & & & & \\
\hline (6) & $R \& D$ intensity (R\&D/sales) & 1.29 & $0.26^{*}$ & $0.10^{*}$ & $0.20^{*}$ & $0.07 *$ & $0.03 *$ & 1 & & & & & & & & & & & \\
\hline (7) & Number of founders in team & 1.16 & $0.09^{*}$ & $0.10^{*}$ & $0.07^{*}$ & 0.01 & $0.13^{*}$ & $0.10^{*}$ & 1 & & & & & & & & & & \\
\hline (8) & Founder with tertiary education $(\mathrm{y} / \mathrm{n})$ & 1.30 & $0.12 *$ & $0.06^{*}$ & $-0.03 *$ & $0.04 *$ & 0.01 & $0.15^{*}$ & $0.27 *$ & 1 & & & & & & & & & \\
\hline (9) & Founder has managerial experience $(\mathrm{y} / \mathrm{n})$ & 1.10 & $0.04 *$ & $0.06^{*}$ & -0.02 & -0.00 & $0.06^{*}$ & 0.02 & 0.02 & $0.04 *$ & 1 & & & & & & & & \\
\hline (10) & Founder has entrepreneurial experience $(\mathrm{y} / \mathrm{n})$ & 1.19 & $0.09 *$ & $0.05^{*}$ & $0.11^{*}$ & $0.04 *$ & $0.05^{*}$ & $0.09^{*}$ & $0.23^{*}$ & $0.12 *$ & $-0.20 *$ & 1 & & & & & & & \\
\hline (11) & Founder's years of industry experience & 1.15 & $-0.02 *$ & 0.02 & $-0.03 *$ & $0.05^{*}$ & $0.04 *$ & $-0.07 *$ & 0.01 & $-0.11^{*}$ & $0.11^{*}$ & $0.05^{*}$ & 1 & & & & & & \\
\hline (12) & Founder has administrative education $(\mathrm{y} / \mathrm{n})$ & 1.11 & $0.07 *$ & $0.06^{*}$ & $-0.03 *$ & 0.01 & $0.03 *$ & $0.05^{*}$ & $0.19^{*}$ & $0.15^{*}$ & $0.04 *$ & $0.12 *$ & $-0.08 *$ & 1 & & & & & \\
\hline (13) & Employees with admin. occupations (share) & 1.05 & 0.02 & -0.02 & $-0.12 *$ & $0.07 *$ & -0.01 & 0.01 & $-0.03 *$ & $0.05^{*}$ & $0.03 *$ & $0.04^{*}$ & $0.05^{*}$ & $0.09^{*}$ & 1 & & & & \\
\hline (14) & Employees with tertiary education (share) & 1.26 & $0.08^{*}$ & $0.09 *$ & $0.04 *$ & $-0.03 *$ & -0.00 & $0.19^{*}$ & $0.15^{*}$ & $0.33^{*}$ & $0.03 *$ & $0.06^{*}$ & $-0.06^{*}$ & $0.03^{*}$ & 0.01 & 1 & & & \\
\hline (15) & Equity capital in year of foundation $(\mathrm{y} / \mathrm{n})$ & 1.18 & $0.09^{*}$ & $0.11^{*}$ & $0.07 *$ & -0.00 & $0.12 *$ & $0.26^{*}$ & $0.11^{*}$ & $0.08^{*}$ & -0.01 & $0.06^{*}$ & $-0.07 *$ & $0.04 *$ & 0.02 & $0.11^{*}$ & 1 & & \\
\hline (16) & Limited liability (y/n) & 1.24 & $0.19^{*}$ & $0.16^{*}$ & $0.22 *$ & $0.03^{*}$ & $0.19^{*}$ & $0.20^{*}$ & $0.31 *$ & $0.32 *$ & -0.00 & $0.28^{*}$ & -0.00 & $0.18^{*}$ & $0.03 *$ & $0.21^{*}$ & $0.15^{*}$ & 1 & \\
\hline (17) & Firm age & 1.20 & $-0.05^{*}$ & -0.01 & $-0.13^{*}$ & 0.01 & $0.12 *$ & $-0.09^{*}$ & -0.01 & $-0.02 *$ & $-0.03 *$ & $-0.05^{*}$ & $0.19^{*}$ & $-0.04 *$ & $-0.09 *$ & 0.01 & $-0.04 *$ & $-0.13^{*}$ & 1 \\
\hline (18) & Risk of business opportunity (log) & 1.13 & $0.06^{*}$ & $0.04 *$ & $0.22 *$ & -0.01 & $-0.07 *$ & $0.11^{*}$ & $0.03 *$ & 0.01 & -0.02 & $0.09 *$ & $-0.09 *$ & $0.09 *$ & $0.04 *$ & $0.05^{*}$ & $0.03 *$ & $0.17^{*}$ & $-0.27 *$ \\
\hline
\end{tabular}


Table 3. First stage before and after entropy balancing

\begin{tabular}{l|c|c}
\hline Dependent variable: & $\begin{array}{c}\text { A } \\
\text { Full Sample } \\
\text { unbalanced } \\
\text { M.E. (S.E.) }\end{array}$ & $\begin{array}{c}\text { B } \\
\text { Full Sample } \\
\text { balanced } \\
\text { M.E. (S.E.) }\end{array}$ \\
Firm has middle management (y/n) & $-0.005(0.002)^{* * *}$ & $-0.008(0.007)$ \\
Number of patents before foundation & $0.015(0.036)$ & $0.073(0.107)$ \\
Innovation opportunities in NACE2 industry & $0.011(0.001)^{* * *}$ & $0.000(0.003)$ \\
Number of dependent employees & $0.020(0.012)$ & $0.004(0.034)$ \\
R\&D intensity (R\&D/sales) & $0.004(0.005)$ & $0.015(0.015)$ \\
Number of founders in team & $0.001(0.013)$ & $-0.016(0.040)$ \\
Founder with tertiary education (y/n) & $0.026(0.011)^{* *}$ & $-0.011(0.032)$ \\
Founder has managerial experience (y/n) & $0.012(0.012)$ & $-0.008(0.034)$ \\
Founder has entrepreneurial experience (y/n) & $0.000(0.001)$ & $-0.000(0.002)$ \\
Founder's years of industry experience & $0.021(0.013)^{*}$ & $0.017(0.036)$ \\
Founder has administrative education (y/n) & $-0.015(0.017)$ & $0.007(0.052)$ \\
Employees with admin. occupations (share) & $0.051(0.016)^{* * *}$ & $-0.044(0.049)$ \\
Employees with tertiary education (share) & $0.051(0.019)^{* * *}$ & $0.017(0.053)$ \\
Equity capital in year of foundation (y/n) & $0.052(0.015)^{* * *}$ & $-0.020(0.047)$ \\
Limited liability (y/n) & $-0.006(0.003)^{* * *}$ & $-0.012(0.009)$ \\
Firm age & $0.052(0.049)$ & $-0.052(0.141)$ \\
Risk of business opportunity (log) & & \\
Industry fixed effects (NACE3-level) & Yes & Yes \\
Year fixed effects & Yes & Yes \\
Constant & Yes & Yes \\
N / Pseudo R-sq. & $5672 / 0.157$ & $5672 / 0.037$ \\
\hline \hline N & & \\
\hline
\end{tabular}

Notes: Marginal effects from probit models. Significance levels: *** 1\%, ** 5\%, *10\%. Cluster-robust standard errors in parentheses. Additional control variables in all regressions: Funding by KfW bank. 
Table 4. Main results

\begin{tabular}{|c|c|c|c|c|}
\hline $\begin{array}{l}\text { Dependent variable: } \\
\text { Product innovation }(\mathbf{y} / \mathbf{n})\end{array}$ & $\begin{array}{c}\text { A } \\
\text { Full Sample } \\
\text { M.E. (S.E.) } \\
\end{array}$ & $\begin{array}{c}\text { B } \\
\text { Full Sample } \\
\text { M.E. (S.E.) } \\
\end{array}$ & $\begin{array}{c}\text { C } \\
\text { Full Sample } \\
\text { M.E. (S.E.) } \\
\end{array}$ & $\begin{array}{c}\text { D } \\
\text { Full Sample } \\
\text { M.E. (S.E.) } \\
\end{array}$ \\
\hline Firm has middle management $(\mathrm{y} / \mathrm{n})$ & 0.043 & 0.043 & 0.044 & 0.044 \\
\hline Number of patents before foundation & $0.010(0.006)^{*}$ & $0.025(0.015)^{*}$ & $0.011(0.006)^{*}$ & $0.025(0.015)^{*}$ \\
\hline Innovation opportunities in NACE2 industry & 0.231 & 0.221 & 0.229 & 0.220 \\
\hline $\begin{array}{l}\text { Middle management * \# patents bef. foundation } \\
\text { Middle management * Innovation opportunities in NACE } 2\end{array}$ & & $0.050(0.029)^{*}$ & 0.049 & $\begin{array}{l}0.049(0.028)^{*} \\
0.042\end{array}$ \\
\hline Number of dependent employees & 0.004 & $0.003(0.002)^{*}$ & $\begin{array}{l}0.004 \\
0.089\end{array}$ & $\begin{array}{c}0.003(0.002)^{*} \\
0.089\end{array}$ \\
\hline $\begin{array}{l}\text { R\&D intensity }(\mathrm{R} \& D / \text { sales }) \\
\text { Number of founders in team }\end{array}$ & $\begin{array}{c}0.092 \\
0.003(0.011)\end{array}$ & $\begin{array}{c}0.091 \\
0.004(0.010)\end{array}$ & $\begin{array}{c}0.089 \\
0.002(0.011)\end{array}$ & $0.003(0.010)$ \\
\hline Founder with tertiary education $(y / n)$ & 0.085 & 0.085 & 0.083 & 0.083 \\
\hline Founder has managerial experience $(\mathrm{y} / \mathrm{n})$ & $0.016(0.023)$ & $0.019(0.022)$ & $0.017(0.023)$ & $0.020(0.022)$ \\
\hline Founder has entrepreneurial experience $(\mathrm{y} / \mathrm{n})$ & $0.002(0.023)$ & $0.000(0.023)$ & $0.003(0.023)$ & $0.002(0.023)$ \\
\hline Founder's years of industry experience & $0.001(0.001)$ & $0.001(0.001)$ & $0.000(0.001)$ & $0.000(0.001)$ \\
\hline Founder has administrative education $(\mathrm{y} / \mathrm{n})$ & $0.033(0.026)$ & $0.034(0.026)$ & $0.033(0.026)$ & $0.033(0.026)$ \\
\hline Employees with admin. occupations (share) & $0.035(0.032)$ & $0.031(0.032)$ & $0.036(0.032)$ & $0.032(0.032)$ \\
\hline Employees with tertiary education (share) & 0.075 & 0.074 & 0.075 & 0.075 \\
\hline Equity capital in year of foundation $(\mathrm{y} / \mathrm{n})$ & $0.029(0.039)$ & $0.027(0.039)$ & $0.027(0.039)$ & $0.026(0.039)$ \\
\hline Limited liability $(y / n)$ & 0.084 & 0.083 & 0.086 & 0.084 \\
\hline Firm age & $-0.008(0.007)$ & $-0.008(0.007)$ & $-0.009(0.007)$ & $-0.008(0.007)$ \\
\hline Risk of business opportunity (log) & $0.063(0.106)$ & $0.027(0.109)$ & $0.060(0.106)$ & $0.024(0.109)$ \\
\hline Industry fixed effects (NACE3-level) & Yes & Yes & Yes & Yes \\
\hline Year fixed effects & Yes & Yes & Yes & Yes \\
\hline Constant & Yes & Yes & Yes & Yes \\
\hline N / Pseudo R-sq. & $5672 / 0.14$ & $5672 / 0.15$ & $5672 / 0.14$ & $5672 / 0.15$ \\
\hline
\end{tabular}

Notes: Marginal effects from weighted probit models. Weights retrieved by entropy balancing. Significance levels: *** 1\%, ** 5\%, * $10 \%$. Cluster-robust standard errors in parentheses. Additional control variables in all regressions: Funding by KfW ba 